\title{
NATURAL HONEY AS A POTENTIAL DIURETIC (Experimental Study)
}

\author{
By \\ Dahab, G.M.; Gaballah, A.M.; \\ Saad, M. A. and El-Sabakhawy, K. M. \\ From \\ Departments of Pharmacology and Biochemistry \\ Faculty of Medicine, Mansoura Univresity \\ Received for Puplication : 7/2/1991
}

\section{INTRODUCTION}

The revelation in the Holy Koran as well as it's decumentation in the hadith clearly described the effectiveness of honey in a variety of diseases (Amir Ali, 1974 and Khan, 1974). Inspite of the attempts that have been made to characterize the pharmacological and scientific aspects of honey, a gap continues to exist between what is known about honey and the hidden miracles of it (Ali, 1989).

In our laboratory while studying the pharmacological effect of honey on blood pressure of dogs an appreciable increase of urine flow was noticed. In addition, earlier reports of other investigators observed that honey could be benefical in treatment of some renal diseases and they suggested that honey could be benefical in treatment of som renal diseases and they suggested that honey through it's effect on adjustment of osmosis could produce diuresis especially in cases of heart failure, renal failure and oedema (Shoker, 1985). These observations stimulated us to explore the potential diuretic effect of honey in a well controlled experimental study in dogs.

\section{MATERIAL AND METHODS}

Fifteen mongrel dogs of either sex, 6 to $10 \mathrm{kgm}$ each were housed under similar conditions and fed similar diet at least for 2 weeks before the experiments. Assay of the diuretic activity was performed according to the method described by Lohmoller et al., MANSOURA MEDICAL JOURNAL 
(1975) and Cohen et al., (1976): After an overnight fasting each dog was anaesthetized with sodium pentobarbital ( $30 \mathrm{mg} / \mathrm{kgm} \mathrm{I.V}$.) and artificially ventilated by a Harvard respirator. The right femoral vein was cannulated for fluid and drug administration. Intravenous saline infusion $20 \mathrm{ml} / \mathrm{kgm}$ body weight was given as a hydrating dose, followed by 0.33 milliliter saline/ $\mathrm{kgm}$ body weight/ minute throughout the experiment. The urinary bladder of the animal was exposed by a midline incision over the lower part of the abdomen. Both ureters were identified, cleared and cannulated about an inch above the urinary bladder with polyethylene tubing. Urine collections from both kidneys were pooled and volumes were measured in graduated cylinders every 20 minutes. Control observations were recorded for one hour. The test compound was then injected intravenously and urine was collected and volume recorded every 20 minutes for a further period of one hour. Blood samples were obtained at the midpoint of each urine collection period. Each urine or serum sample was analyzed for sodium and potassium by flame photometer (Willard et al.,1965) and for chloride concentraVol. 22, No. 1 \& 2 Jan. \& April 1992 tion (Schales, 1953).

The results obtained in the periods following compound treatment were compared with those of the corresponding control periods before compound administratlon. The diuretic activity was calculated acoording to the following equation : (Logmann \& Giraldi, 1958) .

Activity = urinary excretion after treatment / urinary excretion before treatment

The dogs were divided into three groups each of 5 animals. One group was used to demonstrate the response to a standard diuretic drug namely hydrochlorothiazide $2.5 \mathrm{mg} /$ kgm, I.V. (Sweat\&GauL, 1975). The second group received honey intravenously $1 \mathrm{gm} / \mathrm{kgm}$ in a $40 \%$ dil. in normal saline (Deller,1971 and Bizzi,1985). The third group received a glucose fructose maltose (GFSM) mixture in a dose equal to the dose of honey used in the second group and at the same dilution. This mixture was prepared by mixing these sugars together in the same proportions as they are found in natural honey viz: glucose $31 \mathrm{gm} / 100$ $\mathrm{ml}$, fructose $38 \mathrm{gm} / 100 \mathrm{ml}$, sucrose 
$1.3 \mathrm{gm} / 100 \mathrm{ml}$ and maltose $7.3 \mathrm{gm} /$ $100 \mathrm{ml}$ ( Al i, 19 89).

\section{RESULTS}

Hydrochlorothiazide $2.5 \mathrm{mg} / \mathrm{kgm}$ I.V. significantly augmented the volume of urinary output, urinary sodium, chloride and to a less extend potassium excretion. The diuretic effect started immediately after hydrochlorothiazicie injection and reached maximum in the 2nd collection period and started to decline in the 3rd collection period of the drug phase (Table I).

Table II demonstrates that I.V. honey $(1 \mathrm{gm} / \mathrm{kgm})$ produced prompt and significant increase in urine volume, sodium, potassium and chlorlde excretion. These effects also reached maximum values in the 2 nd collection period and started to decrease by third collection period although there was still significant diuretic effects as compared to the corresponding control period. The diuretic and saluretic activity of honey is more or less equal to that of hydrochlorothiazide, but honey had less kaluretic effect (Table IV).

I.V. injection of GFSM mixture (1 $\mathrm{gm} / \mathrm{kgm}$ ) produced no significant changes of urine flow, sodium, potassium or chloride excretion (Table III). Serum sodium, potassium and chloride concentrations were maintained unaltered in all groups, except for slight hypokalaemia in the group treated with hydrochlorothiazide (Table V).

\section{DISCUSSION}

Hydrochlorothiazide was selected as a standard diuretic drug because it has a moderate potency and an average duration of action, these make comparative study more expressive. The diuretic effect of I.V. hydrochlorothiazide in dogs had been demonstrated early by Baer et al., (1959) and Beyer \& Baer, (1959) . It was stated that diuresis started immediately after I.V. injection of chlorothiazide or hydrochlorothiazide and reached maximum within 30 minutes. hydrochlorothiazide significantly inerease urine volume, sodium, chloride and to a less extent potassium. Chloride ion appears to be the main attending anion accompanying cation excretion (Beyer, 1958 and Lohmoller et al., 1975). This pattern of diuretic effect of hydrochlorothiazide as well as the magnitude of this effect, compare vourably with the response obtained in MANSOURA MEDICAL JOURNAL 
the present study. The only significant change in serum electrolytes following I.V. hydrochlorothiazide injection is slight hypokalaemia, this is also in agreement with Lohmoller et al., (1975).

Honey $1 \mathrm{gm} / \mathrm{kgm}$ I.V. produced a statistically significant augmetation in urine output and urinary excretion of sodium, chloride and to a less extent of potassium. The pattern of response is largely comparable to that of hydrochlorothiazide, it started immediately, reached a maximum in the 2nd 20 minutes collection period. Furthermore, the potency of diuretic activity is more or less equal to that of hydrochlorothiazide with similar marked natriuresis covered with comonsurate increase of chloride ion excretion but kaluresis. The finding that honey produced less kaliuresis than hydrochlorothiazide could largely explain why honey did not produce significant hypokalaemia like hydrochlorothiazide. The intravenous injection had been documented to be a safe route for administration of honey Deller (1971) used I.V. injection of honey for few days in treatment of eczema, also, Bizzi (1985) used honey I.V. in a $40 \%$ Vol. 22, No. 1 \& 2 Jan. \& April 1992 dilution during labour to get less painful delivery.

The present study is by far the first report on the diuretic effect of honey. It may be argued that the possible mechanism of diuretic effect of honey is through an osmotic action of it's hypertonic sugar content. However, this assumption seems incorrect because a mixture prepared of glucose - fructose - sucrose - maltose (GFSM) in the same proportions as they are found in natural honey failed to produce any diuretic effect in the present study. The possibility that honey could act as acidifying diuretic could be suggested, since honey is known to be acidic in nature PH 3.6 (White, 1975). However, the magnitude of the diuretic activity of honey is much higher than could be expected from an acidifying agent. Thorefore, the mechanism of action of honey could not be solely through this mechanism. Honey was found to inhibit pepsin enzyme activity in the stomach, possibly through it's colloidal nature that cause adsorption of the enzyme and/or due to its sugar acid oontent as gluconic acid (Baillie\&Anderson, 1968 and $\mathrm{He}-$ gazy et nl.,1981). Accordingly, it could 
be assumed that honey may interfere with renal tubular enzyme activity and affect tubular transport of ions.

Moreover, renal prostaglanains (PGE2 and PGF2) were reported to have natriuretic effect in man (Lee et al., 1971 a \& b) and animals (Fulgraff et al., 1974 and Fine \& Trizha, 1977) when administered intra-arterially or intravenously. Consequently, theories have appeared which designated an important role of prostaglandins as mediators of natriuresis (Dunn \& Hood, 1977). Since honey was documented to counteract indomethacin induced inhibition of prostaglandins synthesis (Ali et al., 1990), it is likely that the diuretic effect of honey could be, at least in part may be, mediated through an action on renal prostaglandins.

Finally, the hidden merits of honey which are not yet uncovered to human can't be ignored (Ali, 1989). The diuretic effect of honey may be due to some of these hidden miracles

Although the various mechanisms of action and site of action at renal tu- bules have not been elucidated, this is the frist study which provides a controlled scientific evidence for the diuretic activity of honey. However, it is worthy to suggest, that further studies of the diuretic effects of honey at different doses and for different durations and by various routs of administration and it's diuretic effect in conditions of acidosis or alkalosis as well in oedematous animals. Also, determination of the site of action by different techniques are required to complete the study of the diuretic effect of this effective and notably safe potential diuretic and to ascertain its clinical potential. In addition, assessment of the effects of honey on the renal tubular enzyme activity, renal haemodynamics and renal prostaglandins are also needed in order to explore the possible underlying mechanism (s) of the diuretic effect of honey.

\section{SUMMARY}

In this study the potential diuretic effect of honey was investigated in anaesthatized dogs and oompared to hydrochlorothiazide as a standard diuretic drug.

MANSOURA MEDICAL JOURNAL 
Intravenous administration of honey $1 \mathrm{gm} / \mathrm{kgm}$ in a $40 \%$ dilution in normal saline produced significant augmentation of volume of urine output, urine sodium, chlorlde and to less extent potassium excretion. The increase in cation excretion is covered with commonsurate increase of chloride ion i.e. chloride ions appears to be the main attending anion. The diuretic effect of honey starts immediately after administration and reachs maximum after 20 to 40 minutes. The pattern of diuretic effect of honey as well as the magnitude of this effect, compare favourably with the response to

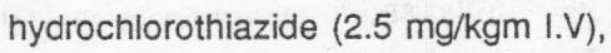
However, honey has the advantage that it produces less kaliuresis. Measurement of serum concentration of sodium, chloride and potassium following administration of honey or hydrochlorothiazide revealed that concentrations of these ions are not altered except the potassium concentration which shows mild hypokalae- mia in dogs treated with hydrochlorothiazide.

A mixture of glucose-fructose - sucrose - maltose (GFSM) in the same proportions as they are found in honey was tested in a group of dogs in a dose of $1 \mathrm{gm} / \mathrm{kgm}$ i.e. equal to the dose of natural honey, this mixture failed to produce any diuretic effect. Such finding could suggest that the diuretic effect of honey is not attributed to its sugar content. Although the various mechanisms of action or the site of the diuretic effect at the nephron have not been elucidated, this is the first study which provides a controlled scientific evidence for the potential diuretic effect of honey. These preliminiry results suggest that honey may be used clinically as a safe diuretic. However, further investigations are required to explore the mechanism (s) of this property and fully to ascertain it's clinical potential.

Vol. 22, No. 1 \& 2 Jan. \& April 1992 
Dahab, G. M.; et al....

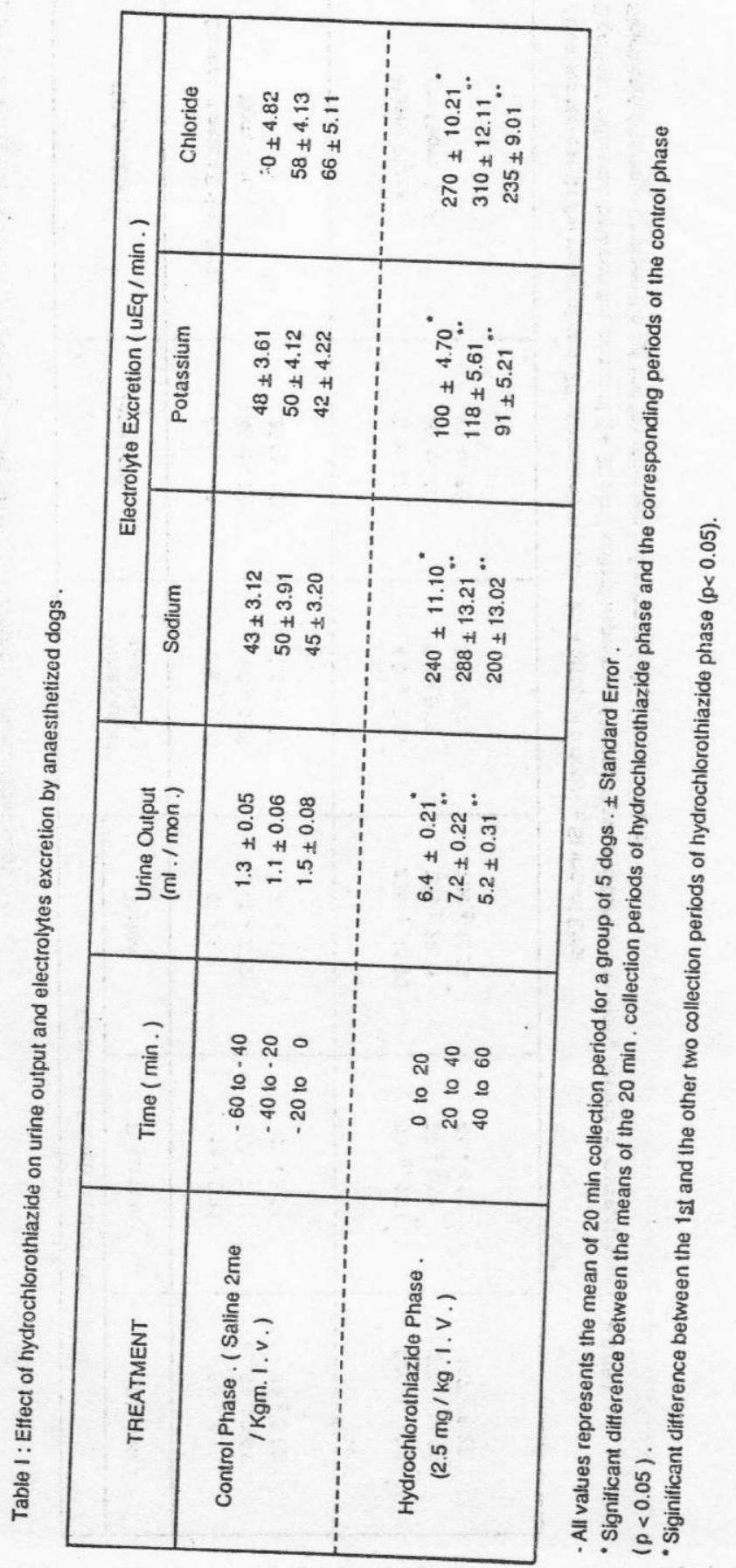

MANSOURA MEDICAL JOURNAL 


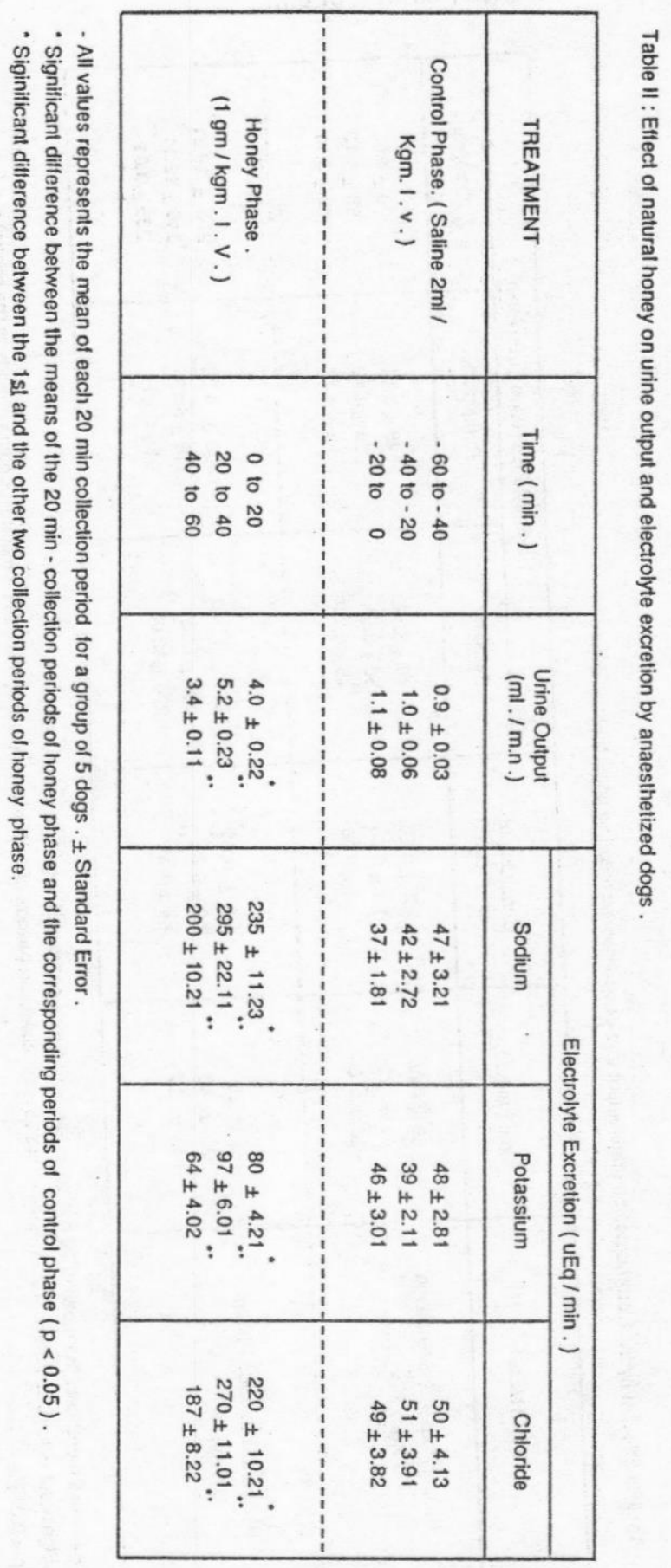

Vol. 22, No. 1 \& 2 Jan. \& April 1992 
Dahab, G. M.; et al....

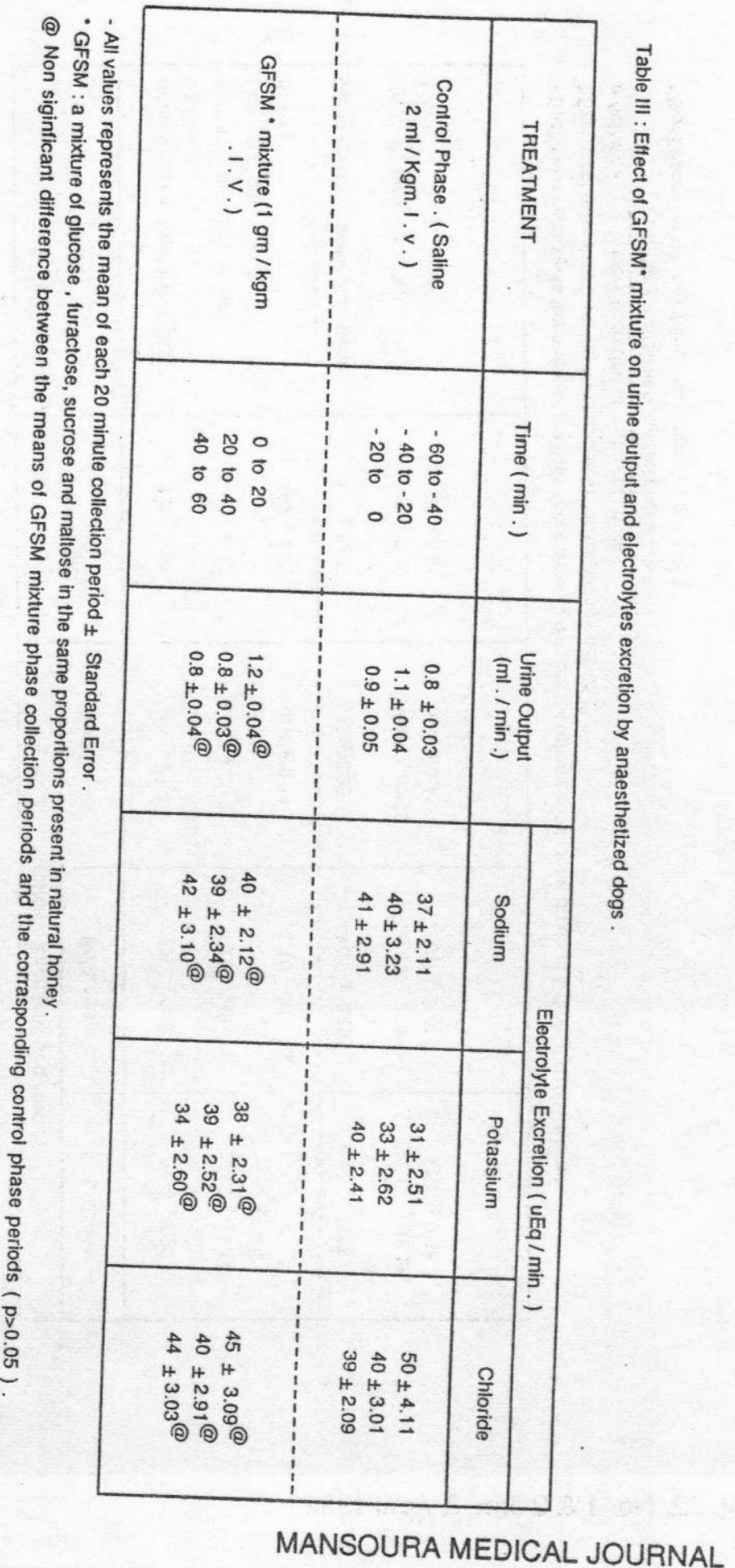




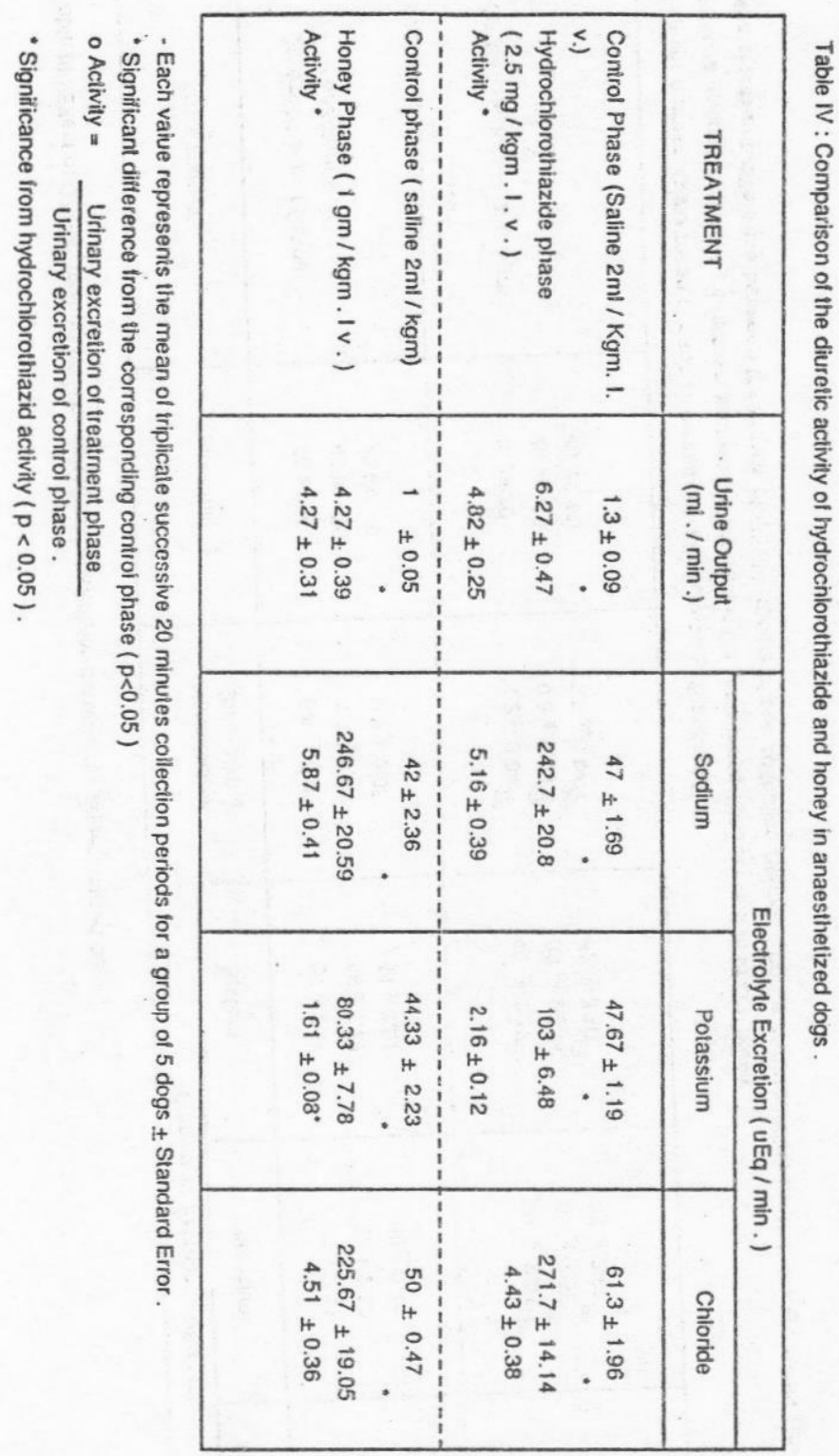

Vol. 22, No. 1 \& 2 Jan. \& April 1992 
Dahab, G. M.; et al....

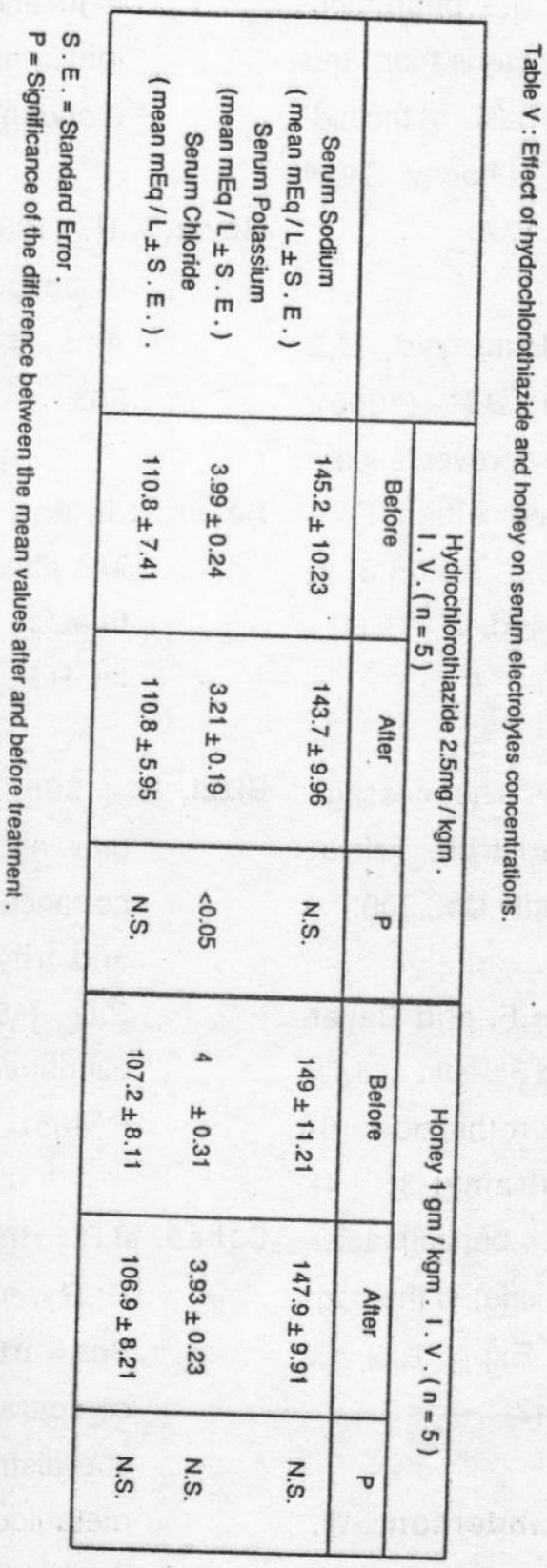

MANSOURA MEDICAL JOURNAL 


\section{REFERENCES}

Ali, A.T.M. (1989) : The pharmacological characterisation and the scientific basis of the hidden inraoles of honey, Saudi Med. J., 10: 177.

Ali, A.T.M. and Al-Humayyd, M.S and Maden, B.R. (1990): Natural honey prevents indomethacin and ethanol induced gastric lesion:3 in rats. Saudi Med, J., 11 (4) : 275.

Amir - Ali, H . (1974) : The message of the koran 1st ed. Tokyo: Cherles E.Tuttle Co., 300.

Baer, J.E. ; Russo, H.F. and Beyer K.H. (1959) : Sluretic activity of hydrochlorothiazide (6chloro-7-sulfamyl-3, 4dihydro-1, 2, 4-benzothiadiazine -1,1- dioxide) in the dog. Proc. Soc. Expr. Biol. \& Med,, 100: 442.

Baillie, A.J. and Anderson, W. (1968) : Macroanionic inhi- bition of peptic activity by high and low molecular we ight macroanions. Nature, (London), 218: 770,

Beyer, K.H . (1958) : The mechanism of action of chlorothiazide. Ann. N.Y. Acad. Sci., 71: 363.

Beyer, K.II. and Baer, J.E. (1959) : The pharmacology of chlorothiazide and its analogues. Int. Rec. Med., $172: 413$.

Bizzi, B. (1985) : In New trends in growing of Bees and the importance of honey in nutrition and treatment. By Shoker, S.D., (1985), United Co. for distribution. Demeshk, Syria P. 405.

Cohen, M.R.; Hinsch, E.; Vergona, R; Ryan, J. Kolis, S.J. and Schwartz, M.A. (1976) : A comparative diuretic and tissue distribution study of bumetanide and furosemide in the dog. J. Pharmacol. and

Vol. 22, No. 1 \& 2 Jan. \& April 1992 
Exp. Ther., 197 (3) : 697.

Deller, J. (1971) : In new trends ingrowing of Bees and the importance of honey in nutrition and treatment. By Shoker, S,D.. ( 1985) united Co. for distribution, Demeshk, Syria, P. 401,

Dunn, M.J. and Hood,V.L. (1977) : Prostaglandins: and the $\mathrm{ki}$ dney Am. J. Physiol., 233 (3): $F 169$.

Fine, L.G . and Trizha,W. (1977) : Influence of prostaglandin on sodium transport of isolated medullary nephron segments. Am, J. Physiol., 252: F 383 .

Fulgraff, G.; Brandenbusch, G. and Hcintze,g. (1974): Dose response relation of the renal effects of PGA1,PGE2 and PGF2\&. Prostaglandins, 8 : 21.
Hegazy, M.R. ; El-Zayat, A.F. and Ibrahim, N. (1981) : Effect of some mucopolysaccharides on experimental gastric ulcer in rats. Proc. Conference of pharmacological and drug evaluation Cairo, Abstract, P.26.

Khan, M.M. (1974) : The translation of meanings of Sahih-Bukhari Vol.VIII, 1st edit. Al-Madina Al-Munawara : Islamic Univ., 395 - 453.

Lee, J.B.; Kannegeisser, H.; Toole, J.O. and Westura, E. (1971a): Hypertension as renomedullary prostaglandins, a human study of antihypertension effects of PGE1. Ann.Acad.Sci., 180:218.

Lee, J.B. ; M.c Giff, J.C. ; Kannegeisser, H.; Aykent,Y.Y.; Mudd, J.G. and Frawley, T.F. (1971 b) : Prostaglandin $A_{1}:$ antihypertensive and renal effects. Ann. Intern. Med., $47: 703$.

MANSOURA MEDICAL JOURNAL 
Logmann,W. and Giraldi, P. (1958) :

Diuretic activity of chlorothiazide derivatives. Nature, 182 (4) : 1510 .

Lohmoller, G.; Lohmoller, R.; Pfeffer, M.; Pfeffer, J.M. and Frohlic h, E. D. (1975) : Mechanism of immediate hemodynamic effects of chlorothiazide. Am. Heart. J. , 89 (4) : 487.

Schales, 0. (1953) : Standard methods of clinical chemistry, Vol. I, Acad. Preas, New York, P. 37.

Shoker, S.D. (1985) : New trends in growing of Bees and the importance of honey in nutritis and treatment. United Co.for distribution, Demeshk, Syria, P. 417 - 420 .

Sweat, G.S. and Gaul, S.L. (1975) : Attenuation of hydrochlorothiazide induced hypokalaemia by $\mathrm{B}$-adrenergic blockers. Eur. J. Pharmacol., 32 (2): 370 .

White, J.A. (1975) : Honey A comprehensive study, In : Heinemann E.C ed.London,157.

Willard, H.H.; Merritt, L.L. and Dean,J.A. (1965): Instrumental methods of analysis, 4th ed. Van Mostrand, New York. 


\section{دراسة تجبية لعسبل النحل الطبيعى كمدر للبول

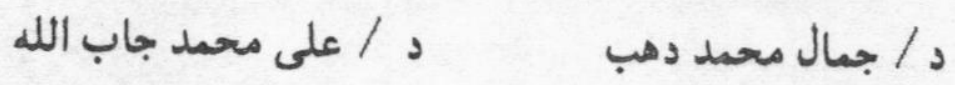

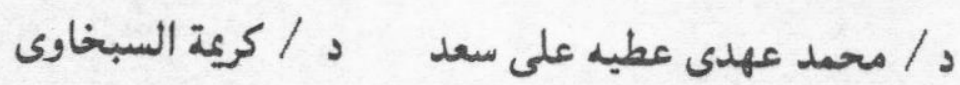 من اتسام الغارماكولوجى والكيمياء الحيوية بكلية الطب - جامعة المبصوية}

تم فى هذا البحث دراسة مدى فاعلية عسل النحل الطبيعى كمدر للبول فى الكلاب المخفدره ومتارنة منعوله بتأثير احد مدرات البول المعروفه ( الهيدروكلوروثبازيد ) )

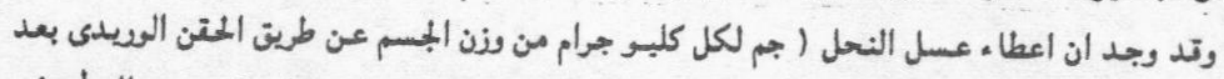

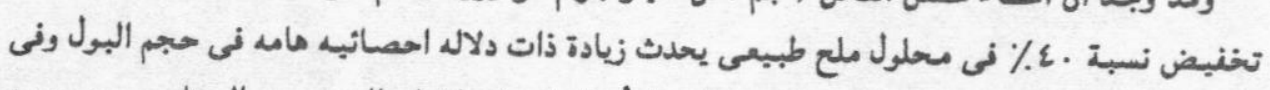

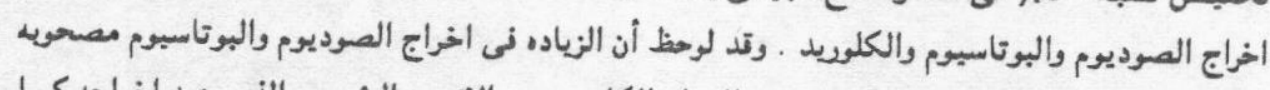

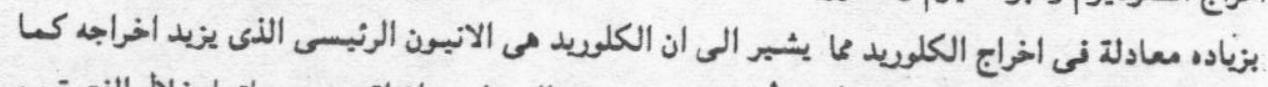

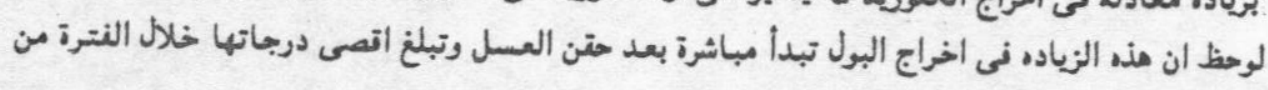

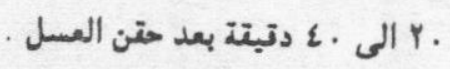

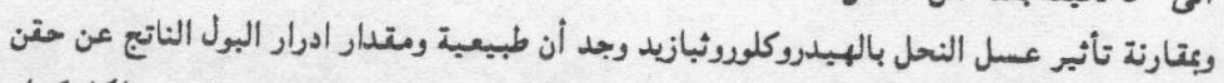

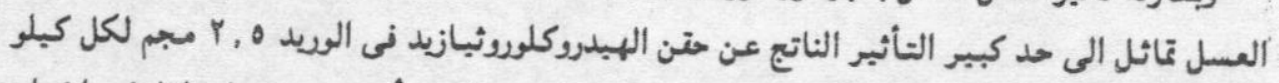

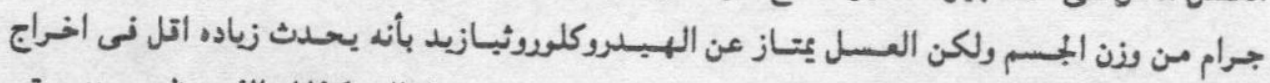

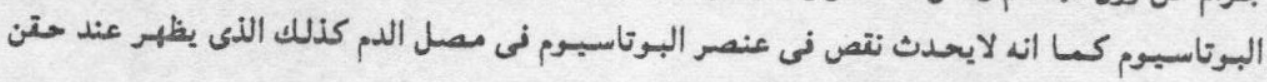

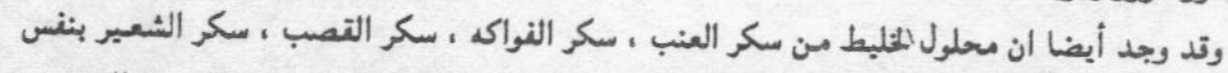

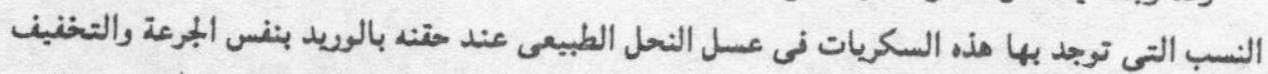

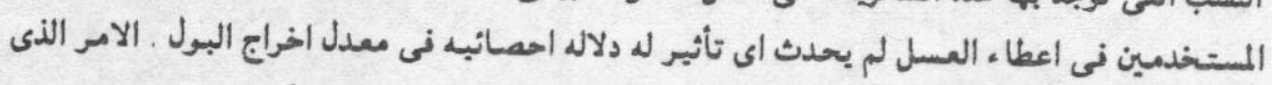

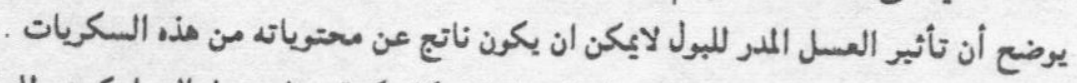

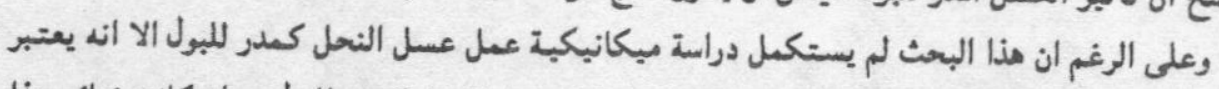

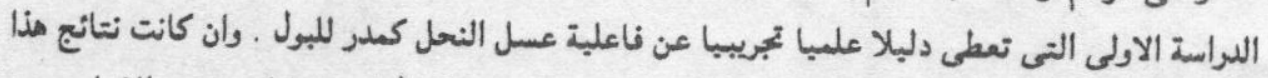

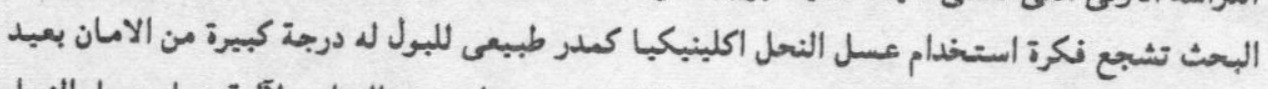

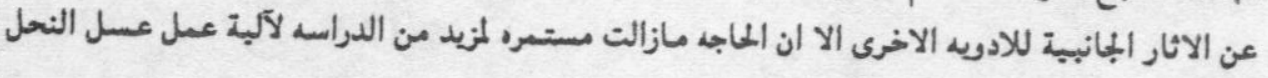
وللتأكد من مدى فاعليته فى الاتسان 
